\title{
Interfacing age: Diversity and (in)visibility in digital public service
}

\author{
Maria Sourbati, University of Brighton \\ Contact: School of Media, University of Brighton, Watts Building, Lewes Road, Brighton BN2 4GJ, UK. \\ E-mail: m.sourbati@brighton.ac.uk \\ https://orcid.org/0000-0001-5374-735X
}

Eugène F. Loos, Utrecht University

Contact: Utrecht University School of Governance, Bijlhouwerstraat 6, 3511 ZC, the Netherlands.

E-mail: e.f.loos@uu.nl

Accepted manuscript version

Suggested citation: Sourbati, M and Loos, E F (2019) 'Interfacing age: Diversity and (in)visibility in digital public service', Journal of Digital Media \& Policy, 10(3): 275293, doi: 10.1386/jdmp_00003_1

\begin{abstract}
This article revisits the concepts of 'diversity' and 'visibility', from the perspective of age relations to consider how these key metrics in the assessment of social inclusion through media representation can be usefully applied to the analysis of digital public service interfaces. Against the backdrop of changes in the age composition of populations, and an expanding role of digital media in 'digital by default' public service provision age remains a neglected dimension of social inequality in media and communications research. This article investigates questions of diversity and social inclusion in old age drawing on a study of visual imagery in public sector websites in the United Kingdom. The analysis integrates insights from media, technology studies, communications policy and critical social gerontology. We identify three patterns in visual imagery: (1) stereotypical representations of group membership as homogenous in terms of age groups, sex, health status and ethnicity, with older adults typically represented as white, (un)healthy men or women; (2) new visibilities, of older adults as socially and culturally diverse groups and (3) new approaches to inclusive digital service design where age becomes an invisible social demographic. We discuss implications for policy and research into diversity, digitalization and digital public service interfaces.
\end{abstract}

Keywords: Age, digital by default, digital public service, diversity, older people, public service interfaces, (in)visibility 


\section{Introduction}

Population ageing and digitalization are held to be the two lines of societal development that are leading to pervasive change in the ways we live our lives. The number and proportion of older people in the population increases (United Nations 2015) and the role of digital connectivity continues to expand as the Internet becomes the platform for our transactions with the government and the market. The two have come to be interrelated: ' $[w]$ hile the development towards an ageing population has been interpreted as a challenge for $[\ldots]$ contemporary welfare societies, digitalization has instead been perceived as a potential partial solution to the problem' (Olsson et al. 2019: 56). Population ageing has been commonly portrayed as a burden, a battle to be fought against (Phillipson 1998; Biggs 1999; Walker 2012). At the same time, old age is constructed as a dimension of digital inequality (Marshall and Katz 2016). Societal and policy responses to what is understood as the 'problem of aging' emphasize both the impact of changes in the age composition of populations on the planning of future social and economic policy goals (European Commission 2015) and the contribution of digital information and communication technologies (ICTs) to improving contact with and services to the ageing population (European Commission 2012; Olsson et al. 2019). Dominant narratives of old age as a burden, a battle to be fought against, and something individuals aim to reverse through technology and consumption, are sutured to neo-liberal notions of efficiency and the restructuring of the social care delivery system (Raisborough Barnes et al. 2014: 4; Macnicol 2015).

This article critically investigates current trends in the visibility of old age in digitally mediated public service information provision within the broader context of changes in social welfare models and digital by default citizen-government transactions. Our analysis brings together perspectives from media and technology studies, communications policy and social gerontology. We use the concept of 'media' to refer to choices individuals make over time (Fernández-Ardèvol et al. 2017: 40-41) to communicate with each other and to reach out to services and information. In this article we draw on data from the United Kingdom. Digital media-technological infrastructures feature as a key dimension in Europe's responses to 'the problem of ageing' (European 
Commission 2015) and in national digital inclusion agendas (see e.g. Ofcom 2017; Good Things Foundation (GTF) 2017; Centre for Ageing Better 2018). Digital communications systems have been the 'default' option in public service provision during the last five years in the United Kingdom (Cabinet Office 2014) with similar developments digital public services happening internationally, including the EU countries, (European Commission 2018 2019), North America (Milakovich 2012) and Australia (Corydon et al. 2016). As digital capability becomes intrinsic to public services, access to social welfare and transactions with government require engagement with digital interfaces. This article has two interrelated aims: First, to investigate the visibility of older people online in public service websites. Second, to consider how 'diversity' and 'visibility', historically key metrics in the assessment of social inclusion through media representation can be usefully applied to the analysis of digital public service interfaces.

The concept of diversity is receiving renewed attention as a perspective to recognize the complex interactions of social-economic, demographic and cultural identity, along such axes as gender, race, class, ability and sexual orientation (Taşgan-Kok et al. 2017). Historically, in media studies, visibility has been a prime modality of social representation (Rocher 2002) achieved through imagery with imagery generating recognition through visibility. In this approach, visibility 'breeds identification and makes it possible' (Brighenti 2007: 333) ordering the world and our knowledge of it (Van Veeren 2018). Imagery has been a means for institutions to entice engagement with information in digital interfaces. Visual interfaces are designed to target user attention (McCullough 2013; Ash 2015). The concept of 'interface' describes both the medium of digital content or software and discourses about the users of this content or service (Stanfill 2015) with the two dimensions interacting, according to Andersen and Pold (2014 n. pag.): ' $[\mathrm{w}]$ ith a representational dimension, technology becomes cultural - and reversely, representation becomes technological'.

We examine the homepages of UK public organizations providing services for older adults. We turn our attention on trends in visual imagery aimed at older adults using a sample of archived web pages from 2013 and 2016 a period of technological, organizational and cultural shift towards a digital 'by default' economy. We compared 
this data with the situation in 2019, when the digital government service design standards and accessibility regulations were deployed across all public sector organizations (https://www.gov.uk/guidance/accessibility-requirements-for-public-sector-websites-andapps). During those years the proportion of older adults using the Internet has risen considerably faster than for the general population. In the United Kingdom, 70 per cent of adults aged 65-75 were using the Internet in 2013 (Office for National Statistics (ONS) 2013a) rising to 78 per cent in 2017 (ONS 2017). In 2018, more than twice as many people over 75 used the Internet as in 2011 (ONS 2018).

The next section introduces dominant cultural constructions of old age with reference to social gerontology and media and technology scholarship. The third section introduces media diversity as both a normative principle and a policy instrument to promote inclusive, or 'universal', service in (analogue) communications, and discusses its relevance in a digital media and information environment. The fourth and fifth sections present and discuss our study of website imagery related to old age. The final section concludes the discussion of emerging (in)visibilities of 'old' age in digitally mediated public services.

\section{Older people as the homogenous Other}

Unlike our cultural and sociological sensitivity to ageing as a long and complex process involving the interaction of an individual and their environment with many and diverse variables, multiple identities and the many social divisions that define an individual's lifetime experiences, the concept of old age is often chronologically defined (Macnicol 2015: 3). Old age is most commonly understood as a point in time. The term older 'generation', frequently used to mean 'cohort', defines groups by reference to their common age range as a shared location in terms of chronology (Vincent 2003: 31, 33). Older adults are understood to be members of a single generational group, despite belonging to groups spanning several decades of birth dates (from $50+$ to $100+$ years). In the process, age, ageing and later-life experiences are conceptualized through categorical homogenization and othering (Loos 2013; Torres 2015; Ylänne 2015; Zubair and Norris 
2015; Loos et al. 2017; Loos and Ivan 2018). Differences within each group are minimized and differences between them become their defining characteristic. This kind of temporalized conceptions of age is built into the twentieth century social welfare models, where chronological age has been the basis for granting or denying access to health and social care services, education and retirement benefits. Accordingly, the possibilities of old age have been delimited through public service design and regulations such as rules determining access to housing, recreation and medicine protocols. Places like kindergartens and after-school clubs, older people's day-centres and nursing homes have thus been built and operated as enclosed spaces with prescribed membership (Vincent 2003: 164-65; Hagestad and Uhlenberg 2005: 345).

Culturally entrenched and public policy-orientated perspectives of chronological age have been mirrored in study design bias. The dominant social-medical research and policy agenda has led to the almost universal social construction of 'older people' as a vulnerable social category in gerontology (Zubair and Victor 2015: 963; Zubair et al. 2012; Leontowitsch 2012). What sociologists of age have critiqued as a dearth of empirical investigations into complex, heterogeneous dynamics of old age as lived experience (Riley, 1987) was illustrated in a systematic review of empirical studies published in six American gerontology journals: 'despite the recent emphasis [...] on the importance of diversity and variability in how individuals age the continuity of current research practices with those prevailing in the 1980s is remarkable' (Stone et al. 2017: 166). This minimizing of complexity in experiences of place, community and technology comes with a failure to recognize the role of changing combinations of structural circumstances, identity (Phillipson 2015), class (Phillipson 2007) ethnicity ${ }^{i}$ (Torres 2015) and gender (Traies 2014) through life course limiting our understanding of implications for the lives of older adults (Hendricks and Hatch 2009: 440; Katz 2013). What Nelson and Dannefer call 'aged heterogeneity' to describe an increase in inter-individual diversity through cumulative life experience (Nelson and Dannefer 1992; Stone et al. 2017), can often lead to an accentuation of complex dynamics of inequality ${ }^{\mathrm{ii}}$ among those belonging to the same age groups (Vincent 2003: 129-30). 
Age relations and choices in the technological landscape have similarly been overlooked in media and ICT research (Hagberg 2012: 101-02; Givskov 2017) as older people are frequently treated as a 'residual category' encompassing all ages above 50 or 60 years (Friemel 2016: 326). Research attention to relationships of inequality, stratification age hierarchies and intersectional orders of identity remains rare (Calasanti and King 2011). Research on older people and new media has mostly drawn on cohort-based understandings of age and media practice, where the former becomes an explanation of the latter, as in the popular digital native-immigrant binary (Prensky 2001) and policyorientated 'digital divide' and 'digital inclusion' agendas (Givskov and Deuze 2018). A growing number of studies have underlined the need for a stronger focus on the lived experience of growing old, internal diversity of generational groups and their contextual, collective and situated character. (Livingstone and Helsper 2007; Bennett et al. 2008; Sourbati 2009; Hargittai 2010; Helsper and Eynon 2010; Hagberg 2012; Loos 2012 , 2013; Hargittai et al. 2017; Loos 2018; Givskov and Deuze 2018).

Across the humanities and the social sciences old and advanced age have been predominantly constructed through cohort centrism and categorical homogeneity, mostly derived from a single, typically white cohort (Riley 1987: 2). Within social gerontology scholarship this construction is based on 'crude' biomedical and welfarist perspectives (Macnicol 2015: 3; Zubair and Norris 2015). In media and communication studies agebased explanations of technology use and counterpart cohort-centric constructions of age draw from what Givskov and Deuze call 'an outdated mode of conceptualizing the relationship between people and media' (2018: 409). The next section discusses media diversity as a public policy goal to promote social inclusion, noting the limitations of inherited conceptual and policy frameworks, before turning its attention to the potential of digital interface design for conceptualizing the relationship between media technology and inclusion.

\section{Diversity as a value in the design of media access}

Diversity has been widely accepted as a core value of universalism in electronic communications (Lowe 2016; Van Cuilenburg 1999) and social policy (Burgelman 
1999). Despite its status as a fundamental principle of access, inclusion and expression, and consequent use as a policy instrument to assess institutional structures of public service broadcasting there has not been a generally accepted, consistent demarcation of the dimensions of media diversity (Helberger et al. 2018: 193; Helberger 2012; Napoli 2011). Diversity in media has been functionally described as a relationship of social balance and equilibrium, achieved through 'free and equal access to a social communications system that $[\ldots]$ provides for the information and communication needs in society' (Van Cuilenburg 1999: 183). Diversity goals in communications policy have comprised tolerance, empathy and intercultural understanding, the development of cultural taste and personal fulfilment. Concerns about democracy and inclusion have always been linked to diversity, at least implicitly (Helberger et al. 2018). Thus defined, a diverse media system contributes to a level of inclusion through exchange of ideas that reflects a given balance of interests, ideas and viewpoints. The emphasis of media diversity as a public policy goal has been on consensus and social reproduction (Helberger et al. 2018: 195).

Historically, in media, diversity policies have been targeted through supply-side measures, aiming to influence the content choices available for consumption. Most commonly, content diversity has referred to the variety of broadcast programme types or genres, the range of ideas and viewpoints presented, and (less so) demographic dimensions relating to persons and groups depicted in the media (Aslama and Napoli 2010; Napoli 2011). Age relations have not been a major focus in media regulation, with the exception of controls to protect minors from exposure to content deemed unsuitable for children, and incentives to support children's radio and television broadcasting, not paralleled by other examples of age-based demographic diversity. Mirroring cultural norms, older age has been marginalized in representational mass media politics, a position shared with 'minority groups [...] underprivileged and disadvantaged social categories, disabled persons, etc. [sic]' (Council of Europe 2007: paragraph. 2).

Media diversity has been most explicitly applied to broadcasting, adding complexity to its translation outside the mass media domain (Braman 2007) as technological and institutional change in networked ICTs transformed modes of media production, 
distribution, access and consumption prompting a shift in media research towards a conception of the active audience (Livingstone 2004a), user-led content choices (Ohm 2008) and socially diversified mediated interaction (Lievrouw and Livingstone 2006). By the end of the twentieth-century digital ICTs were cast in public policy as 'empowerment tools' (Fortunati 2014) that afforded consumers the opportunity to decide whether, how and for which purposes these are to be used for access to information, communication and services. The requirement of going online for social interactions of a private and public nature gave rise to a different set of demand-side questions (Napoli 2011; Aslama and Napoli 2010), including media literacy (Livingstone 2004b), user capability (Sourbati 2012) choice making and how media users find the content/services to satisfy their potentially diverse needs (Helberger 2011; Helberger et al. 2018).

The study of supply side choices in networked digital media landscapes is shifting attention to the design of media and information contexts where user decision making occurs. Accordingly, research is highlighting the role of decision guidance (Selinger and Seager 2012) or content navigation through editorial intelligence (Miel and Faris 2008), and informational choice architecture (Yeung 2017). Lammes (2016) has shown how approaches to the design of digital access entail assumptions about the nature and role of the interface, conceptualized as a mediator of social relations. Thus conceptualized interfaces are not a mimetic or direct representational portal of visual information, but have 'agency in how meaning is produced'(Lammes 2016:1023). According to this theoretical conception 'information is always transformed via the interface' (ibid.). Interfaces can therefore be used as lenses to examine the social logic at work in the production of both the services and their users: particular choice environments bear on the users of a digital service, both in terms of what they are allowed to do and, ultimately, who they are (Petersson 2016). In her empirical study Stanfill (2015) demonstrated how website design arises from specific normative claims and beliefs and reinforces cultural common sense. This kind of claims about purpose and appropriate use 'both demonstrate[e] an understanding of users and buil[d] a set of possibilities' into the object of access (Stanfill 2015: 1060). In the following section we take this perspective to investigate to which extent older adults become visible online, drawing on an empirical study into the visual imagery used on the websites of public service organizations. 


\section{Older adults in digital public service Local Authority healthcare information provision in the United Kingdom}

We conducted content analysis of the adult social care services homepages run by Local Authorities (LAs) in United Kingdom's five largest most ethnically diverse cities, where, according to national Census data, older adults comprise a growing diversity of ethnic groups ${ }^{\mathrm{iii}}$ (Simpson 2013 based on Census 2011 data): Birmingham, Bradford, Leicester, Manchester and the city of London. In the United Kingdom, social care and support services are a public service provided by local councils. We examined sixteen home pages at three points in time, in 2013, 2016 and 2019. These comprised the websites run by the councils of Birmingham, Bradford, Leicester and Manchester, and the twelve inner city London Boroughs (Camden, Greenwich, Hackney, Islington, Lambeth, Lewisham, Southwark, Kensington and Chelsea, Hammersmith and Fulham, Tower Hamlets, Wadsworth and Westminster).

Following the steps of Loos' study into how senior citizens' organizations portray their members online (Loos 2013), we sought to gain insight into how e-public service websites portray older people ${ }^{\mathrm{iv}}$ at three points in time, during the implementation of the 'digital by default' programme of public service transformation and after its completion. Our first sample comprises pages from 2013 when LAs started implementing changes on their legacy websites, after the first e-government service guidelines were issued. In 2013 United Kingdom Government also published details of their planned changes to the social welfare benefits system, making online the 'default' mode of access to informational services, requiring people who needed social care support to apply online and manage their claim through an online account (Office for National Statistics (ONS) 2013b). In the context of this policy LAs had to redesign their websites to meet government 'digital by default' targets. Our second sample was from 2016 and comprised the updated pages of the same services. ${ }^{\mathrm{v}}$ By 2016 LAs had implemented plans for 'digitally inclusive imagery and language' for government, public, private and voluntary sector partners as laid centrally by the UK Government Digital Service (Cabinet Office 2014). We retrieved 32 
archived pages, complete with images, using the Wayback Machine https://archive.org/web/, a free service of the Internet Archive (https://web.archive.org/). Additionally we examined the same websites in July 2019 after the completion of the digital transformation programme.

Using content analysis (Bell 2001) we investigated how visible aspects of diversity were portrayed in the case of older adult group membership. We examined all images depicting people (face; face and body; hands), a total of 43 images, using binary coding in terms of age ('young old', 'old old' and mixed age groups), sex ('woman/man'), health status ('vital' or 'frail') and ethnicity ('white' or BAME) for sameness ('homogeneity') or difference ('diversity') in visual representation.

The analysis of findings focused on how older adults were represented in terms of group membership, more specifically, as homogeneous or a diverse group, using the indicators of sex, health status, and ethnicity, and age/generational category (younger older adults/old, old adults).

\section{Results}

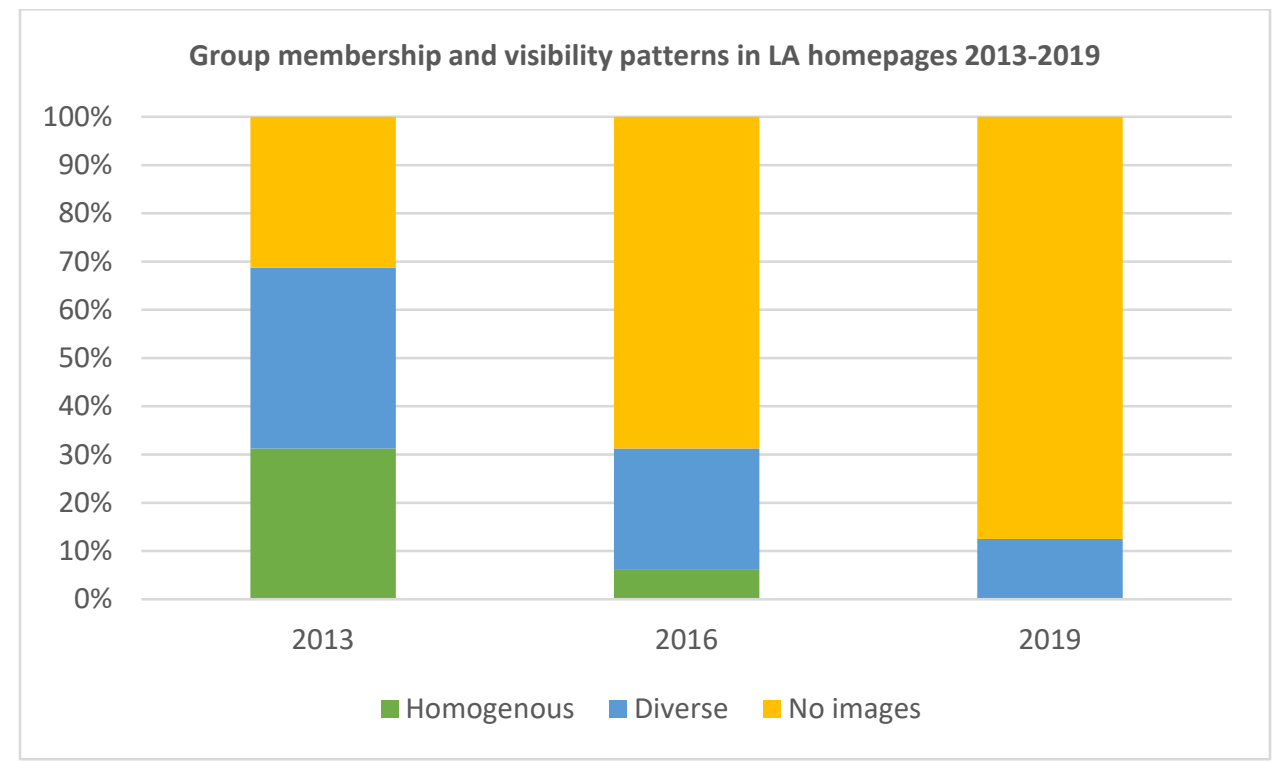


Figure 1: Older adult membership and visibility patterns in LA Social Service homepages in 2013, 2016 and 2019.

\begin{tabular}{|c|c|c|c|c|c|c|}
\hline Council & $\begin{array}{l}\text { No. } \\
\text { images }\end{array}$ & Age & $\begin{array}{l}\text { Health } \\
\text { and } \\
\text { vitality }\end{array}$ & Sex & Ethnicity & $\begin{array}{l}\text { Diverse group } \\
\text { membership }\end{array}$ \\
\hline Birmingham & 4 & $\mathrm{Y}$ & $\mathrm{Y}$ & $\mathrm{Y}$ & $\mathrm{Y}$ & $\mathrm{Y}$ \\
\hline Bradford & 4 & $\mathrm{Y}$ & $\mathrm{Y}$ & $\mathrm{Y}$ & $\mathrm{Y}$ & $\mathrm{Y}$ \\
\hline Camden & 1 & $\mathrm{Y}$ & $\mathrm{Y}$ & $\mathrm{Y}$ & $\mathrm{Y}$ & $\mathrm{Y}$ \\
\hline Greenwich & 1 & $\mathrm{~N}$ & $\mathrm{~N}(\mathrm{~h})$ & $\mathrm{N}(\mathrm{F})$ & $\mathrm{N}$ (white) & $\mathrm{N}$ \\
\hline Ham \& Fulham & 1 & $\mathrm{~N}$ & $N(h)$ & $\mathrm{N}(\mathrm{F})$ & $\mathrm{N}$ (white) & $\mathrm{N}$ \\
\hline Hackney & 1 & $\mathrm{~N}$ & $\mathrm{~N}$ (frail) & $\mathrm{Y}$ & $\mathrm{N}(\mathrm{BAME})$ & $\mathrm{N}$ \\
\hline Islington & 0 & N/A & N/A & N/A & N/A & N/A \\
\hline Lambeth & 1 & $\mathrm{~N}$ & $\mathrm{~N}(\mathrm{~h})$ & Y (couple) & $\mathrm{N}$ & $\mathrm{N}$ \\
\hline Leicester & 4 & $\mathrm{Y}$ & $\mathrm{N}(\mathrm{h})$ & $\mathrm{Y}$ & $\mathrm{Y}$ & $\mathrm{Y}$ \\
\hline Lewisham & 1 & $\mathrm{~N}$ & $N(h)$ & Y (couple) & $\mathrm{N}$ (white) & $\mathrm{N}$ \\
\hline Ken \& Chelsea & 0 & N/A & N/A & N/A & N/A & N/A \\
\hline Manchester & 0 & N/A & $\mathrm{N} / \mathrm{A}$ & $\mathrm{N} / \mathrm{A}$ & $\mathrm{N} / \mathrm{A}$ & $\mathrm{N} / \mathrm{A}$ \\
\hline Southwark & 0 & N/A & N/A & N/A & $\mathrm{N} / \mathrm{A}$ & N/A \\
\hline Tower Hamlets & 3 & $\mathrm{Y}$ & $\mathrm{Y}$ & $\mathrm{Y}$ & $\mathrm{Y}$ & $\mathrm{Y}$ \\
\hline Wandsworth & 0 & N/A & N/A & N/A & $\mathrm{N} / \mathrm{A}$ & N/A \\
\hline Westminster & 1 & $\mathrm{~N}$ & $\mathrm{~N}(\mathrm{~h})$ & $\mathrm{Y}$ & $\mathrm{Y}$ & $\mathrm{Y}$ \\
\hline $\begin{array}{l}\text { Number of } \\
\text { images featured in } \\
\text { homepages }\end{array}$ & 22 & & & & & \\
\hline $\begin{array}{l}\text { Pages with } \\
\text { Diverse } \\
\text { depictions }\end{array}$ & & 5 & 4 & $9 * *$ & 6 & \\
\hline $\begin{array}{l}\text { Pages with } \\
\text { homogenous } \\
\text { depictions }\end{array}$ & & 6 & $7 *$ & $2 \#$ & 5 & \\
\hline $\begin{array}{l}\text { Pages not } \\
\text { including images }\end{array}$ & & 5 & 5 & 5 & 5 & \\
\hline
\end{tabular}




\begin{tabular}{|c|c|c|c|c|c|c|}
\hline Council & $\begin{array}{l}\text { No. } \\
\text { images }\end{array}$ & Age & $\begin{array}{l}\text { Health \& } \\
\text { vitality }\end{array}$ & Sex & Ethnicity & $\begin{array}{l}\text { Diverse group } \\
\text { membership }\end{array}$ \\
\hline Birmingham & 0 & N/A & N/A & $\mathrm{N} / \mathrm{A}$ & $\mathrm{N} / \mathrm{A}$ & N/A \\
\hline Bradford & 0 & N/A & N/A & $\mathrm{N} / \mathrm{A}$ & $\mathrm{N} / \mathrm{A}$ & N/A \\
\hline Camden & 0 & $\mathrm{~N} / \mathrm{A}$ & N/A & $\mathrm{N} / \mathrm{A}$ & $\mathrm{N} / \mathrm{A}$ & N/A \\
\hline Greenwich & 2 & $\mathrm{Y}$ & $\mathrm{Y}$ & N/A & $\mathrm{Y}$ & $\mathrm{Y}$ \\
\hline Ham \& Fulham & 7 & $\mathrm{Y}$ & $\mathrm{Y}$ & $\mathrm{Y}$ & $\mathrm{Y}$ & $\mathrm{Y}$ \\
\hline Hackney & 1 & $\mathrm{~N}$ & $\mathrm{~N}$ & $\mathrm{Y}$ & N (BAME) & $\mathrm{N}$ \\
\hline Islington & 0 & $\mathrm{~N} / \mathrm{A}$ & N/A & $\mathrm{N} / \mathrm{A}$ & N/A & N/A \\
\hline Lambeth & 0 & N/A & N/A & N/A & N/A & $\mathrm{N} / \mathrm{A}$ \\
\hline Leicester & 6 & $\mathrm{Y}$ & $\mathrm{Y}$ & $\mathrm{Y}$ & $\mathrm{Y}$ & $\mathrm{Y}$ \\
\hline Lewisham & 5 & $\mathrm{Y}$ & $\mathrm{Y}$ & $\mathrm{Y}$ & $\mathrm{Y}$ & $\mathrm{Y}$ \\
\hline Ken \& Chelsea & 0 & N/A & N/A & N/A & N/A & N/A \\
\hline Manchester & 0 & N/A & N/A & N/A & N/A & N/A \\
\hline Southwark & 0 & N/A & N/A & N/A & N/A & N/A \\
\hline Tower Hamlets & 0 & N/A & N/A & N/A & N/A & N/A \\
\hline Wandsworth & 0 & N/A & N/A & N/A & N/A & N/A \\
\hline Westminster & 0 & N/A & N/A & $\mathrm{N} / \mathrm{A}$ & $\mathrm{N} / \mathrm{A}$ & N/A \\
\hline $\begin{array}{l}\text { Number of } \\
\text { images featured in } \\
\text { homepages }\end{array}$ & 21 & & & & & \\
\hline $\begin{array}{l}\text { Pages with } \\
\text { diverse depictions }\end{array}$ & & 4 & 4 & 4 & 4 & \\
\hline $\begin{array}{l}\text { Pages with } \\
\text { homogenous } \\
\text { depictions }\end{array}$ & & 1 & 1 & 0 & 1 & \\
\hline $\begin{array}{l}\text { Pages not } \\
\text { including images }\end{array}$ & & 11 & 11 & 12 & 11 & \\
\hline
\end{tabular}

Table 2: Older adults' images in LA Social Service homepages (2016)

\begin{tabular}{|c|c|c|c|c|c|c|}
\hline Council & $\begin{array}{l}\text { No. } \\
\text { images }\end{array}$ & Age & $\begin{array}{l}\text { Health and } \\
\text { vitality }\end{array}$ & Sex & Ethnicity & $\begin{array}{l}\text { Diverse group } \\
\text { membership }\end{array}$ \\
\hline Birmingham & 0 & N/A & N/A & N/A & N/A & $\mathrm{N} / \mathrm{A}$ \\
\hline Bradford & 0 & N/A & N/A & N/A & N/A & N/A \\
\hline Camden & 0 & N/A & N/A & $\mathrm{N} / \mathrm{A}$ & N/A & N/A \\
\hline Greenwich & 0 & $\mathrm{~N} / \mathrm{A}$ & $\mathrm{N} / \mathrm{A}$ & $\mathrm{N} / \mathrm{A}$ & N/A & N/A \\
\hline Ham \& Fulham & 6 & $\mathrm{Y}$ & $\mathrm{Y}$ & $\mathrm{Y}$ & $\mathrm{Y}$ & $\mathrm{Y}$ \\
\hline Hackney & 0 & N/A & N/A & N/A & N/A & N/A \\
\hline Islington & 0 & N/A & N/A & N/A & N/A & $\mathrm{N} / \mathrm{A}$ \\
\hline Lambeth & 0 & N/A & N/A & N/A & N/A & N/A \\
\hline Leicester & 6 & $\mathrm{Y}$ & $\mathrm{Y}$ & $\mathrm{Y}$ & $\mathrm{Y}$ & $\mathrm{Y}$ \\
\hline Lewisham & 0 & N/A & N/A & N/A & N/A & N/A \\
\hline Ken \& Chelsea & 0 & N/A & N/A & N/A & N/A & N/A \\
\hline Manchester & 0 & N/A & N/A & N/A & N/A & N/A \\
\hline Southwark & 0 & N/A & N/A & N/A & N/A & N/A \\
\hline Tower Hamlets & 0 & N/A & N/A & N/A & N/A & N/A \\
\hline Wandsworth & 0 & N/A & N/A & N/A & N/A & N/A \\
\hline Westminster & 0 & N/A & N/A & N/A & N/A & N/A \\
\hline $\begin{array}{l}\text { Number of } \\
\text { images featured in } \\
\text { homepages }\end{array}$ & 12 & & & & & \\
\hline $\begin{array}{l}\text { Pages with } \\
\text { diverse depictions }\end{array}$ & & 2 & 2 & 2 & 2 & \\
\hline $\begin{array}{l}\text { Pages with } \\
\text { homogenous } \\
\text { depictions }\end{array}$ & & 0 & 0 & 0 & 0 & \\
\hline $\begin{array}{l}\text { Pages not } \\
\text { including images }\end{array}$ & & 14 & 14 & 14 & 14 & \\
\hline
\end{tabular}

Table 3: Older adults' images in LA Social Service homepages (2019). 
In 2013 older adults were visible in eleven of the sixteen homepages (see Table 1). Six LAs, Camden, Westminster, Bradford, Leicester, Birmingham and Tower Hamlets featured images of mixed ethnicity groups of older women and men of different health statuses. Five LAs (Lewisham, Greenwich, Lambeth, Hackney, Hammersmith and Fulham) featured older adults as members of non-diverse groups. In terms of health, sex, ethnicity and age/generation, in most of the images across the sample older people tended to be depicted as having a homogenous health status (seven out of eleven), as looking healthy ${ }^{\mathrm{vi}}$ (with only one image featuring frail individuals) and as belonging to the same generation ( six webpages featuring single-generational groups and five featuring adults from different generations). In terms of ethnicity, diverse membership was also slightly higher than ethnically homogenous membership with six pages featuring people from ethnically diverse backgrounds against five featuring ethnically non-diverse backgrounds. The newly designed pages of another five LAs, Islington, Southwark, Manchester, Kensington and Chelsea and Wandsworth, had implemented user-friendly accessibility standards comprising text-only or graphic icon-based navigation buttons, which did not feature any age-related imagery.

By 2016, when UK LAs had launched their newly designed websites implementing the government digital strategy (simpler, clearer and faster that can be accessed via mobile devices, such as phones and tablets, or computers) (Cabinet Office 2013) older people were either depicted as members of diverse communities or not visible at all: four LA websites were using ethnically diverse imagery of adult women and men off different adult ages (dark and fair skinned old adults alone or in the company of others), one included an image of a black heterosexual couple, and eleven used text and graphic icononly user interfaces (see Table 2). In 2019 this pattern was found in fourteen out of sixteen LA websites (see Table 3).

Our findings show that during the last decade there has been a mix of visual cultural approaches to old age, reflecting as well as modifying long held social attitudes (see Figure 1). In 2013, five of the sixteen homepages depicted older people as homogenous groups, with their membership defined through binaries of frailty/vitality and as ethnically non-diverse. These depictions reflect dominant and popular understandings of 
age defined through homogenous, chronology-based group membership. Situating this pattern in the context of Internet take up back in 2013, the imagery used in these homepages can be seen to 'stand for' the older adults who were not typically using the Internet and online services for themselves. Though no direct relationship between image, visibility and inclusion can be found, depictions of the intended users of a website can encourage or incite, or discourage or prevent (Stanfill 2015: 1060 citing Foucault 1990). As levels of Internet diffusion continued to increase across adult populations, and the digitalization of government information and public services was well underway, the redesigned LA pages started to display a greater range of images of older adults. These images featured more mixed groups of adult women and men of different generations, with different dis/ability statuses, from a range of ethnic groups (e.g. Camden). During that period, a new trend emerged following the issuing, by central government, of new service design principles and toolkits for page layouts. Digital public service design guidelines covered iconography (Moorhouse 2013) and illustrations (GOV.UK n.d.) to promote user-friendly navigation, text-based neutrality, retiring icons and minimal use of illustrations, showing actions or artefacts (not people) when there is a 'clear user need'. It quickly became the standard approach of text-only or text and graphic icon-based navigation. In 2013 ten out of the sixteen pages examined included images of older people and six used text or icons only navigation. In 2016 the pattern had been reversed with five pages displaying images and eleven comprising text or graphics only interfaces. By 2019 fourteen out of the sixteen webpages used text and icons only and did not include pictures.

Our findings indicate two directions of change in the visualities of old age online: first, away from limited visibilities and stereotypical depictions of older adults as frail or healthy members of homogenous groups, and towards an increased, more diverse visual presence of people from different ethnic backgrounds, with a range of fitness, ability and vitality statuses. In this pattern, found in six council homepages in 2013 and in four in 2016, visibility remains a central dimension of representation. Second, moving towards the opposite direction, the visual disappearance of age from digital public service interfaces, a predominant trend since 2016. This trend follows the GOV.UK accessibility strategy which advocates a universal, user-friendly semiology of 'functionings' as 
opposed to 'identities' (Duggin 2016), building 'for needs, not audiences' (Government Digital Service 2012). Correspondingly, the cultural markers of old age as a time that is not experienced homogenously by all became visible on the computer (mainly) screen for a brief time only to disappear again in inclusive digital design. In this new paradigm LA adult social care websites, and more generally government digital interfaces, are not excluding (nor including) any older groups by means of visual representation.

\section{Conclusions}

As our societies are ageing and digitalizing 'by default', and the so-called digital generations grow older too, age relations, technology and the media come to the fore of public policy and discourses on social inclusion. In this article we highlighted the significance of trends in ageing and digitalisation and critically examined how they play out in relation to social inclusion. We investigated firstly, patterns in the visibility of old age in digital public services websites. Online public services are a substantial part of digital welfare economies, not only in England, United Kingdom, where our study was undertaken, but also across Europe and internationally. Local government and public sector organizations providing services that are essential to the lives of millions of older adults have been playing a key role in making older citizens visible online during the past decade. The visual imagery we investigated illustrated both long-held views on old age, articulated as homogeneities and binaries of frailty and fitness, cultural background (race; ethnicity) and sex (heterosexual couples) as well as new visibilities of old age as a more diverse social reality. We also found new approaches to digital public service design relating back to questions surrounding diversity, representation and inclusion. Our study revealed how digital public service provision can have effects, including indirect ones, towards a more diverse visual representation, and the role of public policy can play in relation to visibility (e.g. accessibility design guidelines). Finally, the current changes to government digital services, as in the examples of LA websites from 2016 and 2019 illustrate how questions of diversity become more complex in their assessment for the 
purposes of access to public services and social inclusion. The idea of service inclusiveness through visual invisibility merits further investigation.

Secondly, we asked whether inherited concepts of media diversity can be useful to probe research and policy responses to older citizens and out ageing societies. Far from being homogenous older groups are socially, culturally and economically situated into diverse and intersecting categories of gender, race, class, ability and sexual orientation. Can age inclusiveness be assessed using metrics of 'media' diversity? Are legacy, broadcast media diversity metrics of representation useful to a facilitate access to a digital service? With ageing going hand in hand with a more intense diversification of populations on the one hand, and increases in digitalization and the role of data in government on the other, a normative perspective on visual or pictorial diversity does not easily translate to inclusiveness metrics. As service user needs and groups are more finely categorized in digital services, the re/presentation of ever more finely graded categories becomes nontenable. From this perspective the absence of pictures can be a more socially 'inclusive' visual strategy. That is not to say cultural norms and codes are not at work. ${ }^{\text {vii }}$ Diversity remains a core sensitivity against what Feenberg (1995: 87) calls the 'unexamined cultural assumptions literally designed into technology itself'. Viewed in the context of digital data and age relations, invisibility can augment discrimination during the life course, resulting in further marginalization of those who remain unseen. Big data approaches currently favoured by government can be expected to accentuate this kind of effects due to age-related bias in available learning datasets (biased samples), and in available tools (algorithms) (Rosales and Fernández-Ardèvol 2019). If unnoticed, these gaps in digital data infrastructures have the potential to increase the scope of exclusion as an unintended and indirect effect of technology.

This article took public service digital interface design as the site to examine power relations of age, media technology and inclusion. It investigated common patterns in the visibility of old age online and how cultural attitudes to age may map onto public policies using the example of digital public service design. We did not set out to investigate intentionality in the decisions of local government but how popular stereotyping and attributions of difference reflect on digital interfaces. With the international community 
called to recognize sensitivities to structural age discrimination ('WHO $\mid$ Ageism' 2017) all-age inclusive public service design can be expected to receive more public and media attention. Our analysis is situated against the backdrop of global trends in demographic change, characterized by a constant increase in the median age of populations (Price Waterhouse Coopers 2016), and of the digital transformation of public services around the world. As societies are ageing and access to services becomes digital by default representations and abstractions of both age and technology are bound to receive increased research and policy attention. In our article we focused on western societies in which digitization is one of the driving forces for societal change concurring with Joyce et all's view of technology as a 'major forc[e] in the social construction of ageing, and ageing [as] an often unacknowledged component of technoscientific imagination and practice' (Joyce et al. 2015: 157). Visual representations may no longer feature as the primary or the sole mode of feedback between people and institutions in mediated public service communication. At the same time, emerging trends in visibility and digital mediation, through digital public interfaces are a new context for the critical consideration of cherished values of social and media diversity. In this article we demonstrated how age relations, a neglected dimension of demographic diversity can and should - be part of this.

\section{References}

Andersen, C. U. and Pold, S. (2014), 'Manifesto for a post-digital interface criticism | The new everyday', The New Everyday. A Mediacommons Project. January 10, 2014. http://mediacommons.org/tne/pieces/manifesto-post-digital-interface-criticism Accessed 30 September 2019

Ash, J. (2015), The Interface Envelope : Gaming, Technology, Power, London: Blumsbury Publishing.

Aslama, M. and Napoli, P. (2010), 'Diversity 2.0: Rethinking audiences, participation, and policies', McGannon Center Working Paper Series. 27

https://fordham.bepress.com/mcgannon_working_papers/27 Accessed 6 August 2018

Bell, P. (2001), 'Content analysis of visual images', in T. Van Leeuwen and C. Jewitt (eds), Handbook of Visual Analysis, London: SAGE, pp. 13-33. 
Bennett, S., Maton, J. A. and Kervin, K. A. (2008), 'The "digital natives" debate: A critical review of the evidence', British Journal of Educational Technology, 39:5, pp. 775-86.

Biggs, S. (1999), The Mature Imagination : Dynamics of Identity in Midlife and beyond, Buckingham: Open University Press.

Braman, S. (2007), 'The limits of diversity', in P. M. Napoli (ed.), Media Diversity and Localism: Meaning and Metrics, Mahwah, NJ: Lawrence Erlaum Associates, pp. 139-50.

Brighenti, A. (2007), 'Visibility: A category for the social sciences', Current Sociology, 55:3, pp. 323-42, doi: 10.1177/0011392107076079.

Burgelman, J.-C. (1999), 'The future of the welfare state and its challenges for communication policy', in A. Calabrese and J.-P. Burgelman (eds), Communication, Citizenship and Social Policy: Rethinking the Limits of the Welfare State, Rowman \& Littlefield Publishers.pp. 125-135.

Cabinet Office (2013), 'Government digital strategy: December 2013 - GOV.UK', Cabinet Office, 10 December, https://www.gov.uk/government/publications/governmentdigital-strategy/government-digital-strategy. Accessed 5 August 2018.

(2014), 'Government digital inclusion strategy - GOV.UK', Cabinet Office, 4 December, https://www.gov.uk/government/publications/government-digital-inclusionstrategy/government-digital-inclusion-strategy. Accessed 30 October 2019.

Calasanti, T. and King, N. (2011), 'A feminist lens of the third age: Refining the framework', in D. C. Carr and K. Komp (eds), Gerontology in the Era of the Third Age : Implications and Next Steps, New York, NY: Springer Pub. Co, p. 67-85.

Centre for Ageing Better (2018), 'The digital age: New approaches to supporting people in later life get online', Centre for Ageing Better, 31 May, doi:

10.31077/ageing.better.2018.05a. https://www.ageing-

better.org.uk/sites/default/files/2018-05/The-digital-age.pdf Accessed 30 September 2019

Corydon, B., Ganesan, V. and Lundqvist, M. (2016), 'Digital by default: A guide to transforming government', McKinsey Center for Government.

https:/www.mckinsey.com/ /media/mckinsey/industries/public\%20sector/our\%20insight s/transforming\%20government $\% 20$ through\%20digitization/digital-by-default-a-guide-totransforming-government.ashx Accessed 30 September 2019

Council of Europe (2007), 'Recommendation CM/Rec(2007)2 of the Committee of Ministers to member states on media pluralism and diversity of media content', Committee of Ministers: Selection and Most Recent Adopted Texts, Council of Europe, CoE Strasbourg. https://go.coe.int/8WkuV Accessed 30 September 2019 
Duggin, A. (2016), 'What we mean when we talk about accessibility - Accessibility', Accessibility Blog gov UK, 16 May, https://accessibility.blog.gov.uk/2016/05/16/whatwe-mean-when-we-talk-about-accessibility-2/. Accessed 1 August 2017.

European Commission (2012), 'eHealth Action Plan 2012-2020 - Innovative healthcare for the 21st century', $\operatorname{COM(2012)~} 736$ Final, European Commission Brussels, 6 December, doi: SWD(2013) 527. https://ec.europa.eu/digital-singlemarket/en/news/ehealth-action-plan-2012-2020-innovative-healthcare-21st-century Accessed 30 September 2019

-- (2015), 'The 2015 Ageing Report. Economic and budgetary projections for the $28 \mathrm{EU}$ Member States (2013-2060)', European Economy Series, European Commission, Directorate General for Economic and financial affairs Brussels, 3 May.https://ec.europa.eu/economy_finance/publications/european_economy/2015/pdf/ee 3_en.pdf Accessed 30 September 2019

- (2019), 'e-Government and digital public services', European Commission Digital Single Market Policies, Updated 27 September 2019 https://ec.europa.eu/digital-singlemarket/en/public-services-egovernment Accessed 30 September 2019.,

Feenberg, A. (1995), Alternative Modernity : The Technical Turn in Philosophy and Social Theory, Berkeley: University of California Press.

Fernández-Ardèvol, M., Sawchuk, K. and Grenier, L. (2017), 'Maintaining connections: Octo- and nonagenarians on digital "use and non-use",, Nordicom Review, 38:1, pp. 3951, doi: 10.1515/nor-2017-0396.

Fortunati, L. (2014), 'Media between power and empowerment: Can we resolve this dilemma?', The Information Society, Routledge, 30:3, pp. 169-83, doi:

10.1080/01972243.2014.896676.

Friemel, T. N. (2016), 'The digital divide has grown old: Determinants of a digital divide among seniors', New Media \& Society, London: SAGE Publications, 18:2, pp. 313-31, doi: $10.1177 / 1461444814538648$.

Foucault, M (1990) The History of Sexuality, Vol. 1: An Introduction. New York: Vintage Press

Givskov, C. (2017), 'Growing old with media technology and the material experience of ageing', European Journal of Cultural Studies, London: SAGE Publications, 21:3, p. 136754941770843 , doi: 10.1177/1367549417708431.

Givskov, C. and Deuze, M. (2018), 'Researching new media and social diversity in later life', New Media \& Society, London: SAGE Publications, 20:1, pp. 399-412, doi: $10.1177 / 1461444816663949$.

Good Things Foundation (GTF) (2017), ‘The real digital divide?', Good Things Foundation (GTF). June 2017. 
https://www.goodthingsfoundation.org/sites/default/files/researchpublications/ofcom_report_v4_links.pdf Accessed 30 September 2019

GOV.UK (n.d.), 'GOV.UK Design System. Design your service using GOV.UK styles, components and patterns', GOV.UK Design Patterns Wiki, https://designsystem.service.gov.uk/. N.d. Accessed 6 August 2018.

GOV.UK Government Digital Service (2012), 'Government design principles GOV.UK', 3 April, https://www.gov.uk/guidance/government-design-principles. Accessed 6 August 2018.

Hagberg, J.-E. (2012), 'Being the oldest old in a shifting technology landscape', in E. F. Loos, L. Haddon and E. Mante-Maijer (eds), Generational Use of New Media, Farnham: Ashgate, pp. 89-106.

Hagestad, G. O. and Uhlenberg, P. (2005), 'The social separation of old and young: A root of ageism', Journal of Social Issues, Wiley/Blackwell (10.1111), 61:2, pp. 343-60, doi: 10.1111/j.1540-4560.2005.00409.x.

Hargittai, E. (2010), 'Digital na(t)ives? Variation in internet skills and uses among members of the "net generation", Sociological Inquiry, Wiley/Blackwell (10.1111), 80:1, pp. 92-113, doi: 10.1111/j.1475-682X.2009.00317.x.

Hargittai, E. and Dobranski, K. (2017), 'Old dogs, new clicks: Digital inequality in skills and uses among older Adu...: EBSCOhost', Canadian Journal of Communication, 42:2, pp. 195-212, doi: 10.22230/cjc2017v42n2a3176.

Hargittai, E.. and Dobransky, K. (2017), 'Old dogs, new clicks: Digital inequality in skills and uses among older adults', Canadian Journal of Communication, 42:2, pp. 195212, doi: $10.22230 /$ cjc. $2017 \mathrm{v} 42 \mathrm{n} 2 \mathrm{a} 3176$.

Helberger, N. (2011), 'Diversity by design', Journal of Information Policy, 1:1, pp. 44169.

- (2012), 'Exposure diversity as a policy goal', Journal of Media Law, Routledge, 4:1, pp. $65-92$, doi: $10.5235 / 175776312802483880$.

Helberger, N., Karppinen, K. and D'Acunto, L. (2018, 'Exposure diversity as a design principle for recommender systems', Information, Communication \& Society, Routledge, 21:2 pp. 191-207, doi: 10.1080/1369118X.2016.1271900. hrhr

Helsper, E. J. and Eynon, R. (2010), 'Digital natives: Where is the evidence?', British Educational Research Journal, 36:3, pp. 503-20, doi: 10.1080/01411920902989227.

Hendricks, J. and Hatch, L. R. (2009), ‘Theorizing lifestyle: Exploring agency and structure in the life course', in V. L. Bengston, D. Gans, N. M. Putney and M. Silverstein (eds), Handbook of Theories of Aging, 2nd ed., New York: Springer, pp. 435-54. 
Joyce, K., Loe, M. and Diamond-Brown, L. (2015), 'Science, technology and ageing', in J. Twigg and W. Martin (eds), Routledge Handbook of Cultural Gerontology, New York: Routledge, pp. 157-64, doi: 10.4324/9780203097090.CH44.

Karppinen, K. (2013), Rethinking Media Pluralism, Fordham University Press.

Katz, S. (2013), 'Active and successful aging. Lifestyle as a gerontological idea', Recherches Sociologiques et Anthropologiques (RS\&A), 44:1, pp. 33-49.

Lammes, S. (2016), 'Digital mapping interfaces: From immutable mobiles to mutable images', New Media \& Society, 19:7, pp. 1019-1033. London: SAGE Publications, p. 146144481562592. doi: 10.1177/1461444815625920.

Leontowitsch, M. (2012), 'Introduction', in M. Leontowitsch (eds), Researching Later Life and Ageing : Expanding Qualitative Research Horizons, Palgrave Macmillan, Basingstoke, UK pp. 1-6.

Lievrouw, L. A. and Livingstone, S. M. (2006), 'Introduction', in L. A. Lievrouw and S. M. Livingstone (eds), Handbook of New Media : Social Shaping and Social Consequences of ICTs, London: SAGE, pp. 1-32.

Livingstone, S. (2004a), 'Media literacy and the challenge of new information and communication technologies', The Communication Review, 7:1, pp. 3-14, doi: $10.1080 / 10714420490280152$.

- (2004b), 'The challenge of changing audiences', European Journal of Communication, 19:1, pp. 75-86, doi: 10.1177/0267323104040695.

Livingstone, S. and Helsper, E. (2007), 'Gradations in digital inclusion: Children, young people and the digital divide', New Media \& Society, London: Sage Publications, 9:4, pp. 671-96, doi: 10.1177/1461444807080335.

Loos, E. F. (2012), 'Senior citizens: Digital immigrants in their own country?', Observatorio (OBS*), OberCom, 6:1, pp. 1-23, doi: 10.15847/obsOBS612012513.

- (2018), 'The organizational use of online stock photos: The impact of representing senior citizens as eternally youthful', Human Technology, 14:3, pp. 366-81, doi: 10.17011/ht/urn.201811224838.

- (2013), 'Designing for dynamic diversity: Representing various senior citizens in digital information sources', Observatorio (OBS*), 7:1, pp. 21-45, doi:

10.15847/obsobs712013639.

Loos, E. F. and Ivan, L. (2018), 'Visual ageism in the media', in L. Ayalon and C. TeschRömer (eds), Contemporary Perspectives on Ageism, Cham: Springer, pp. 163-76, doi: 10.1007/978-3-319-73820-8_11. 
Loos, E., Ivan, L., Fernández-Ardèvol, M., Sourbati, M., Ekström, M., Wilińska, M., Carlo, S. and Schiau, I. (2017), 'Ageing well? A cross-country analysis of the way older people are visually represented on websites of organizations for older people', Journal of Comparative Research in Anthropology and Sociology, 8:2, pp. 63-83.

Lowe, G. F. (2016), 'Psm in the 21st century: What value and which values?'. European Broadcasting Union Media Intelligence Service https://www.ebu.ch/publications/psm-inthe-21st-century Accessed 6 August 2018

Macnicol, J. (2015), Neoliberalising Old Age, Cambridge: Cambridge University Press.

Marshall, B. L. and Katz, S. (2016), 'How old am I?', Digital Culture \& Society, transcript Verlag, 2:1, pp. 145-52, doi: 10.14361/dcs-2016-0110.

McCullough, M. (2013), Ambient Commons: Attention in the Age of Embodied Information, Cambridge, Massachusetts : The MIT Press.

Miel, P. and Faris, R. (2008), News and Information as Digital Media Come of Age, Cambridge, MA: The Berkman Center for Internet and Society

doi: $10.4324 / 9780203815991$.

Moorhouse, G. (2013), 'Retiring our icons', Government Digital Service, Cabinet Office, 18 June, https://gds.blog.gov.uk/2013/06/18/retiring-our-icons/. Accessed 6 August 2018.

Napoli, P. M. (2011), 'Exposure diversity reconsidered', Journal of Information Policy, $1: 1$, pp. 246-59.

Nelson, E. A. and Dannefer, D. (1992), 'Aged heterogeneity: Fact or fiction? The fate of diversity in gerontological research', The Gerontologist, 32:1, pp. 17-23.

Ofcom (2017), 'Access and inclusion in 2016 outcomes for consumers in vulnerable circumstances', Ofcom. 15 March 2017.

https://www.ofcom.org.uk/_data/assets/pdf_file/0030/98508/access-inclusion-report2016.pdf Accessed 30 September 2019

Office for National Statistics (ONS) (2013a), '(Archived Content) Internet access quarterly update, Q2 2013 - ONS', Office for National Statistics (ONS), 14 August 2013 https://webarchive.nationalarchives.gov.uk/20151014064159/http:/www.ons.gov.uk/ons/ rel/rdit2/internet-access-quarterly-update/q2-2013/index.html Accessed 30 September 2019

http://webarchive.nationalarchives.gov.uk/20160107130439/http://www.ons.gov.uk/ons/r el/rdit2/internet-access-quarterly-update/q2-2013/stb-ia-q2-2013.html. Accessed 6 August 2018.

- (2013b), (Archived content) 'Internet access - households and individuals - Office for National Statistics', Office for National Statistics (ONS), 8 August 2013.

https://www.ons.gov.uk/peoplepopulationandcommunity/householdcharacteristics/homei 
nternetandsocialmediausage/bulletins/internetaccesshouseholdsandindividuals/2013-0808

Accessed 30 September 2019.

- (2017), 'Internet users in the UK', Office for National Statistics (ONS), May.

https://www.ons.gov.uk/businessindustryandtrade/itandinternetindustry/bulletins/internet users/2017 Accessed 30 September 2019

— (2018), 'Internet users: UK, 2018', Office for National Statistics (ONS). May

https://www.ons.gov.uk/businessindustryandtrade/itandinternetindustry/bulletins/internet users/2018 Accessed 30 September 2019

Ohm, P. (2008), 'The myth of the superuser: Fear, risk, and harm online', UC Davis Law Review, 41:4, pp. 1327-402.

Olsson, T., Samuelsson, U. and Viscovi, D. (2019), 'At risk of exclusion? Degrees of ICT access and literacy among senior citizens', Information, Communication \& Society, Routledge, 22:1, pp. 55-72, doi: 10.1080/1369118X.2017.1355007.

Petersson, J. (2016), 'Technospatialities and telehealthcare: Unfolding new spaces of visibility', Information, Communication \& Society, Routledge, 19:6, pp. 824-42, doi: 10.1080/1369118X.2015.1061575.

Phillipson, C. (1998), Reconstructing Old Age : New Agendas in Social Theory and Practice, Sage Publications, London, Thousand Oaks and New Delhi.

- (2007), "The "elected" and the "excluded": Sociological perspectives on the experience of place and community in old age', Ageing and Society, Cambridge University Press, 27:3, pp. 321-42, doi: 10.1017/S0144686X06005629.

- (2015), 'Placing ethnicity at the centre of studies in later life: Theoretical perspectives and empirical challenges', Ageing and Society, 35:5, pp. 917-34.

Prensky, M. (2001), 'Digital natives, digital immigrants Part 1', On the Horizon, MCB UP Ltd, 9:5, pp. 1-6, doi: 10.1108/10748120110424816.

Price Waterhouse Coopers (pwc) (2016), 'Five megatrends and their implications for global defense \&amp; security’, Price Waterhouse Coopers (pwc). November 2016 https://www.pwc.com/gx/en/government-public-services/assets/five-megatrendsimplications.pdf Accessed 30 June 2019

Raisborough, J., Barnes, M., Henwood, F. and Ward, L. (2014), 'Stretching middle age: The lessons and labours of active ageing in the makeover show', Media, Culture \& Society, London: SAGE Publications, 36:8, pp. 1069-83, doi:

10.1177/0163443714544997. 
Rocher, G. (2002), 'Les représentations sociales : Perspectives dialectiques', Information sur les sciences sociales, Sage Publications, 41:1, pp. 83-99.

Rosales, A. and Fernández-Ardèvol, M. (2019), 'Structural ageism in big data approaches', Nordicom Review, 40:1, pp. 51-64, doi: 10.2478/nor-2019-0013.

Selinger, E. and Seager, T. P. (2012), 'Ethical decision-making apps damage our ability to make moral choices', Slate, 13 July 2012 https://slate.com/technology/2012/07/ethicaldecision-making-apps-damage-our-ability-to-make-moral-choices.html Accessed 30 September 2019

Simpson, L. (2013), Does Britain have Plural Cities?, The Dynamics of Diversity: Evidence from the 2011 Census, Centre on Dynamics of Ethnicity (CoDE) and The University of Manchester and Joseph Rowntree Foundation January 2013 http://hummedia.manchester.ac.uk/institutes/code/briefings/dynamicsofdiversity/doesbritain-have-plural-cities.pdf Accessed 12 April 2018

Sourbati, M. (2009), “It could be useful, but not for me at the moment": Older people, internet access and e-public service provision', New Media and Society, 11:7, pp. 1083100.

- (2012), 'Disabling communications? A capabilities perspective on media access, social inclusion and communication policy', Media, Culture and Society, 34:5, pp. 57187.

Stanfill, M. (2015), 'The interface as discourse: The production of norms through web design', New Media and Society 17:7, pp. 1059-74.

Stone, M. E., Lin, J., Dannefer, D. Kelley-Moore JA. (2017), 'The continued eclipse of heterogeneity in gerontological research', The Journals of Gerontology Series B:

Psychological Sciences and Social Sciences, Oxford University Press, 72:1, pp. 162-67.

Taşan-Kok, T., Bolt, G., Plüss, L. and Schenkel, W. (2017), A Handbook for Governing Hyper-Diverse Cities, Utrecht: Utrecht University Press. Utrecht University, Faculty of Geosciences, May 2017.

Torres, S. (2015), 'Expanding the gerontological imagination on ethnicity: Conceptual and theoretical perspectives', Ageing and Society, 35:5, pp. 935-60.

Traies, J. (2014), The Lives and Experiences of Lesbians Over 60 in the UK, Doctoral thesis (PhD) University of Sussex, UK, January 2014

United Nations (2015), World Population Ageing 2015, United Nations, New York.

Van Cuilenburg, J. (1999), 'On competition, access and diversity in media, old and new', New Media \& Society, SAGE Publications, 1:2, pp. 183-207, doi:

$10.1177 / 14614449922225555$. 
Van Veeren, E. (2018), 'Invisibilities', in R. Bleiker (ed.), Visual Global Politics, Routledge: Taylor \& Francis Group. London and New York pp. 196-200

Vincent, J. A. (2003), Old Age, London: Routledge and Taylor and Francis Group.

Walker, A. (2012), 'The new ageism', The Political Quarterly, Wiley/Blackwell (10.1111), 83:4, pp. 812-19.

White Riley, M. (1987), 'On the significance of age in sociology', Source American Sociological Review, 52:1, pp. 1-14.

World Health Organisation (WHO) (2017) 'WHO | Ageism' (2017), World Health Organization. https://www.who.int/ageing/ageism/en/ Accessed 26 July 2018

Yeung, K. (2017), “'Hypernudge”: Big data as a mode of regulation by design', Information, Communication \& Society, Routledge, 20:1, pp. 118-36.

Ylänne, D. V (2015), 'Representations of ageing in the media', in J. Twigg and W. Martin, (eds), Routledge Handbook of Cultural Gerontology, Abingdon: Routledge, pp. $369-75$.

Zubair, M., Martin, W. and Victor, C. (2012), 'Doing Pakistani ethnicity the female way: Issues of identity, trust and recruitment when researching older Pakistani Muslims in the UK', in M. Zubair, W. Martin and C. Victor (eds), Researching Later Life and Ageing, London: Palgrave Macmillan UK, pp. 63-83.

Zubair, M. and Norris, M. (2015), 'Perspectives on ageing, later life and ethnicity: Ageing research in ethnic minority contexts', Ageing and Society, 35:5, pp. 897-916.

Zubair, M. and Victor, C. (2015), 'Exploring gender, age, time and space in research with older Pakistani Muslims in the United Kingdom: Formalised research "ethics" and performances of the public/private divide in "the field", Ageing and Society, 35:5, pp. $961-85$.

\section{Notes}

\footnotetext{
${ }^{\mathrm{i}}$ We follow the UK Office for National Statistics (ONS) definition of ethnicity as a 'multi-faceted and changing phenomenon' that may reflect a combination of several features including country of birth, nationality, language spoken at home, ancestral country of birth, skin colour, national or geographical origin, racial group or religion (https://www.ons.gov.uk/methodology/classificationsandstandards/measuringequality/ethnicgrou pnationalidentityandreligion\#different-aspects-of-ethnicity).
} 
${ }^{\text {ii }}$ Particularly during the last part of the life course, many experience a restriction in social space and limited choice in access to adequate housing, leisure, health and communication infrastructure etc. (Vincent 2003: 129-30).

iii This includes ethnic diversity, which is far greater in the city of London than the country as a whole. According to data by the Greater London Authority (2013) the Black, Asian \& Minority Ethnic groups (BAME) constituted the 43 per cent of all adult population and 29 per cent of the $65+$ years of age in 2011 .

${ }^{\text {iv }}$ Adult social care, adult care, health and care, health and social care, health and well-being and services for older people were the most common page tags.

${ }^{\mathrm{v}}$ For the local council of Hammersmith and Fulham we included a page from January 2017 as pages from 2016 were not archived

${ }^{\text {vi }}$ This reflects an international trend. Loos et al. (2017) have been showing a similar result in a cross-country study analysing the way older people are visually represented on websites of organizations for older people

${ }^{\text {vii }}$ We owe this point to Michael Klontzas. 